\title{
Reaction of Zagreb Stock Exchange CROBEX Index to macroeconomic announcements within a high frequency time interval ${ }^{* 1}$
}

\author{
Tomasz Schabek ${ }^{2}$, Bojana Olgić Draženović ${ }^{3}$, Davor Mance ${ }^{4}$
}

\begin{abstract}
The purpose of this study is to analyse Zagreb Stock Exchange CROBEX Index reactions to selected macroeconomic announcements within ultra-short time intervals. We utilize 5-minute rates of returns from September 2017 to March 2018 and 25 macroeconomic announcements. After carefully arranging the data, we ran the regression with dummy variables capturing the exact announcement times. We used heteroscedasticity and autocorrelation consistent (HAC) estimations in order to account for specific characteristics of intraday data and to retain the robustness of the results. Our results indicate that, for short intraday periods, some reactions are statistically significant, but the majority stays insignificant. These conclusions support the semi-strong form of the efficient-market hypothesis and are in line with inferences of similar studies of advanced economies.
\end{abstract}

Key words: emerging markets, Croatian financial market, macroeconomic announcements, intraday returns, CROBEX

JEL classification: $G 1, F 3, E 5, O 2, P 3$

\footnotetext{
Received: 01-06-2019; accepted: 18-12-2019

1 This paper was financially supported by the University of Rijeka project: uniri-drustv-18-61. This paper was financially supported by the University of Rijeka project: uniri-drustv-18-284-1456.

2 Assistant Professor, University of Lodz, Faculty of Economics and Sociology, POW 3/5, 90-255 Lodz, Poland. Scientific affiliation: financial econometrics, finance, behavioral finance, capital markets. Phone: +48 889162263. E-mail: tomasz.schabek@uni.lodz.pl.

${ }^{3}$ Assistant Professor, University of Rijeka, Faculty of Economics and Business, I. Filipovića 4, 51000 Rijeka, Croatia. Scientific interest: capital markets, institutional investors, pension systems.Phone: +385 51 355128.E-mail: bojana.olgic.drazenovic@efri.hr.

4 Assistant Professor, University of Rijeka, Faculty of Economics and Business, I. Filipovića 4, 51000 Rijeka, Croatia. Scientific affiliation: institutional and behavioral economics. Phone: +38551355144.E-mail:davor.mance@efri.hr.
} 


\section{Introduction}

We analyse the reaction of the primary Croatian stock market index - CROBEX to macroeconomic announcements regarding the Croatian economy within an ultrashort time period. Thus, we also test the semi-strong form of the efficient-market hypothesis (e.g. Fama, 1970) on the most liquid component of the Croatian capital market: the CROBEX index of the Zagreb Stock Exchange (ZSE). The relation between macroeconomic announcements, regarding the monetary and real sectors alike, is one of the most interesting topics in finance as it allows not only to test the efficient-market hypothesis but it also has important implications on models describing the capital market equilibrium and variables determining it. In this study, we focus on intraday effects, because lower frequency data intervals (e.g. daily or monthly) usually incorporate broader range of information which does not allow an adequate separation of impacting variables when it comes to specific and systematic risk. From a practitioner's point of view, the answer to the question of significance of economic releases is crucial because many trading strategies involve opening and closing market positions multiple times during a single day. Moreover, actively managed portfolios maximize exposure to certain risks, so the knowledge on macroeconomic factors generating risks and returns on the market is essential for the performance of these portfolios. Policy makers, such as governments and central banks, are also interested in knowing whether these policies will have an impact on stock prices.

Our research is primarily focused on Croatia as to enrich the literature, owing to the fact that there are just few scientific articles discussing the impact of macroeconomic announcements on the Croatian capital market in the context of intraday returns. Different authors agree that the Croatian capital market is a modern capital market completely adjusted to the EU acquis. On the other hand, as its basic underlying features, they note that it is underdeveloped: narrow (with a small number of traders), shallow (with a small order size needed to move the market price) and thus illiquid and inefficient (Benić and Franić 2008; Sajter and Čorić 2009; Buljat et al. 2015). Market illiquidity is even more emphasized in the post-crisis period, with investors being even less active and much more cautious compared to the pre-crisis period (Škrinjarić and Besek 2014). Moreover, Grubišić Šeba (2017) concludes that the Croatian capital market is an exclusive platform for institutional investors, without any significant trading from small investors. Vidović (2013) considers the effects of liquidity on the asset valuation on the Zagreb Stock Exchange (ZSE), but he did not find evidence of liquidity premium on Croatian stock market. This suggest that liquidity or lack of it is not main driver of rates of returns. Benaković and Posedel (2010) analysed the returns on fourteen Croatian stocks in the period from January 2004 to October 2009 using macroeconomic factors by taking into account both the direction and strength of the relation. Positive influence was shown by market index, interest rates, oil prices 
and industrial production, while inflation had a negative one. The authors conclude that, despite the volatility, the investments were not compensated for by higher premium yields. According to these previous studies, we cannot thus reject the weak-form of the efficient-market hypothesis since no excess returns can be earned by using investment strategies based on historical data. The semi-strong form of the efficient-market hypothesis requires prices to adjust rapidly to announced current information without leaving the possibility for abnormal return generation. The semi-strong efficiency in Croatia can be questionable due to narrow and shallow market that could prevent necessary market adaptation speed. In our study, we provide results indicating that market returns react timely and significantly on relevant macroeconomic information; therefore, in this regard, they support semistrong efficiency of Croatian stock market.

The paper is organized as follows: in section two, we present a brief literature review outlining only the most important papers related to the topic, section three contains the used methodology, the section four presents the data, data sources and the empirical analysis. Section five presents the results and discusses the findings. Lastly, in section six, we present our concluding remarks.

\section{Literature review}

The impact of macroeconomic announcements on financial asset returns is broadly discussed in finance literature and the main idea of the efficient-market hypothesis that asset prices reflect all available information has been tested countless times. Recent advancements in computer technology and markets allowed researchers to match the exact moments of announcement with short term rates of returns as intraday data became easier to acquire, especially for developing countries. Many of the initial studies focused on foreign exchange markets as they are more liquid and have longer time series available. A concise review of the recent literature of foreign exchange market intraday studies is presented in Li et al. (2015). Baillie and Bollerslev (1991) and later DeGennaro and Shrieves (1997) provide methodological insight for modelling high frequency data and present their application in empirical investigations of foreign exchange markets. Discoveries related to market reactions (on US macroeconomic news) in ultra-short time-spans for broader range of financial assets are presented in Andersen et al. (2007) where authors discuss cross-sectional dependencies between different markets (bond, stock, and foreign exchange markets) and countries (U.S., Germany, UK). They conclude that fundamental data moves the financial assets prices and causes a spillover effect in analysed markets. In the context of our study, the study of Fatum et al. (2012) should be mentioned, in which heteroscedasticity and autocorrelation consistent (HAC) estimations method was used to verify the impact of the macroeconomic announcements on 5 minutes intraday exchange rate of JPY/USD. We follow their 
method in our research. Fatum et al. (2012) utilize long term time series of intraday data (almost 8 years of data) so they could examine this phenomenon also in the context of different states of economy (expansions and contraction). Unfortunately, our database contains shorter time series. Generally, Fatum et al. (2012) found that particular macro-variables (such as nonfarm payroll employment, GDP, consumer spending) significantly impact the JPY/USD exchange rate. Lahaye et al. (2011) analysed reactions of three different asset classes (foreign exchange, stock index futures and US Treasury bond futures) and conclude that for each of the analysed asset class, macroeconomic news have different impact regarding the appearance of jumps in rate of returns. Recent study of US equity exchange-traded funds (ETF) by Nadler and Schmidt (2016) although based on daily data, confirms the significant impact of macroeconomic announcements (trade balance, ISM manufacturing index, nonfarm payroll) on equity market. Similar conclusions, but regarding futures market (bonds and stock) are presented in Huang (2018). Będowska-Sójka (2013) compared the reactions of the French CAC40 and the German DAX blue chip indices to German and American macroeconomic news. Although the results confirmed that the American announcements have higher impact on volatility, effects of German macro news were also significant or the domestic German market, but also on the French stock market.

With technological progress and data availability, recently, the literature regarding emerging markets also started to develop. Égert and Kocenda (2007) analyzed possible interrelations within three CEE stock markets using five-minute ticker intraday prices for the period between 2003 and 2005. Also, authors expanded their study with interrelations between Western European stock markets (DAX, CAC, UKX ) and stock markets in three CEE markets (BUX, PX-50, WIG-20). They identified a deficiency of stable long-term relations between stock market indices under study but also signs of short-term spillover effects both in terms of stock returns and stock price volatility. Hanousek et al. (2009) studied the reactions of three Central Europe stock markets (Polish, Hungarian and Czech) and confirmed that macro-news, especially foreign, have significant impact on stock markets. Price jumps using highfrequency data as a proxy to market inefficiencies were used in a study by Hanousek and Novotný (2012). Results suggested possible relationships between different market regulation and micro-structures in Prague, Warsaw, Budapest, and Frankfurt stock markets. Gurgul et al. (2016) analysed the impact of US macroeconomic news on Polish WIG20, German DAX and Austrian ATX stock market indices. They found a strong impact of macroeconomic news on the structure of returns, volatility and volume on these three markets. Another contribution to the emerging market literature in analysed context is the study of Frömmel et al. (2015) in which almost half of jumps of Hungarian forint (HUF/EUR) are explained by macroeconomic announcements. Maserumule and Alagidede (2017) report a significant volatility increase in intraday returns of ZAR/USD caused by US and South African news arrival, also they conclude that the cause of the increase of volatility is not only 
the surprise element of macroeconomic announcement but the announcement itself as well. The study of 35 stock markets, including emerging markets, conducted by Nikkinen et al. (2006) shows that developing countries are not affected by US macroeconomic news. Later, Cai et al. (2009) argue that foreign exchange markets of emerging economies become more sensitive to US news. Literature related to central European markets in context of responses to macroeconomic announcements also include: reactions of bond market to US news (Andritzky et al., 2007), central banks verbal comments (Rozkrut et al., 2007), forward guidance (Baranowskicand Gajewski 2016) and central bank public announcements (Brzeszczyński et al., 2017), liquidity and order book dynamics (Bień-Barkowska 2014; Będowska-Sójka 2016), cross-section and time series analysis (Schabek and Maknickienė, 2018).

Regarding Croatia, the study of Logožar and Arnerić (2017) provides evidence of stock market (CROBEX) intraday volatility patterns, but not in the context of macroeconomic announcements. Barbić and Čondić-Jurkić $(2011,2017)$ consider the link between stock indices and macroeconomic variables of developed EU markets and emerging EU member states (Croatian, Czech, Hungarian, Polish and Slovenian markets) with the focus on testing market efficiency. Although there are several sources examining the relationship between CROBEX and selected macroeconomic or other variables (Jakšić 2008; Hsing 2011; Peša and Festić 2012; Shim et al. 2017), we observe the lack of research focused on the impact of macroeconomic announcements on CROBEX.

\section{Methodology}

Since the main idea of the EMH cannot be tested directly as the full information set is not known, we proceed by testing the hypothesis of the impact of individual information on CROBEX. In order to evaluate the impact of macroeconomic announcements on short-term rates of return from CROBEX, we estimate the following equation:

$r_{t}^{C R O}=\beta_{0}+\sum_{j=1}^{J} \sum_{k=-K}^{K} \beta_{j, k} \cdot D_{t-k}^{j}+\sum_{m=1}^{M} \beta_{m} \cdot r_{t-m}^{C R O}+\sum_{n=-K}^{K} \beta_{n} \cdot r_{t-k}^{E U R 50}+\sum_{i=1}^{i=76} \beta_{i} \cdot D_{i, t}+\varepsilon_{t}$

where: $r_{t}^{C R O}$ is the five-minute rate of return from the CROBEX index, $D_{t-k}^{j}$ is the dummy variable taking value 1 when given $j$-th macroeconomic announcement from Croatian market was released, value 0 in other cases. $J$ is the number of types of macroeconomic announcements (eight types: Current Account Balance, GDP change year to year, Industrial Output change year to year, Money Supply M1 Level, Real Wages year to year, Retail Trade Real year to year, Trade Balance and Unemployment Rate). $r_{t-k}^{E U R 50}$ is five-minute rate of return of EUR50 Index (introduced as control 
variable in order control external information which could impact CROBEX). $D_{i, t}$ are $i$-th dummy variables that take value of one for each 5-minute interval within given day (controlling for intraday periodicity). $\mathrm{K}$ is lag of each $j$-th macroeconomic news announcements and return of EUR50 Index, $\mathrm{M}$ is the lag of five-minute returns of CROBEX, $\beta_{0}, \beta_{j, k}, \beta_{m}, \beta_{n}$ and $\beta_{i}$ are the estimated coefficients. The values of $\mathrm{M}$ and $\mathrm{K}$ were selected according to Akaike information criteria. Note that $k$ starts from $-\mathrm{K}$ which means that we also include lead $\left(_{\mathrm{t}+\mathrm{k}}\right)$ variables and one contemporaneous variable $\left(_{t}\right)$ in our equation. We set the starting value of $K$ and $M$ to be equal 10 . Due to such approach we can check the reactions of CROBEX after the release as well. Although optimal from the Akaike information criteria point of view, values for $M$ and $K$ are given by $M=10$ and $K=1$, we decide to set $K$ to 2 in order to investigate broader time span before and after the announcement. For robustness purposes, we also tested other lags and leads specifications, but this did not change our results significantly. For reasons of non-normality, non-stationarity and strong heteroscedasticity of our time series (verified by Lagrange multiplier ARCH test) we cannot estimate equation (1) via the classical ordinary least squares (OLS) method, although coefficient estimates would still be consistent (but not efficient) in the case of utilizing the OLS. In order to solve this problem, we use heteroscedasticity and serial-correlation robust (HAC) standard errors, proposed by Newey-West (1987). A similar approach was used in Fatum et al. (2012). HAC standard errors should only be used in cases of large samples of data. Fortunately, our study fulfils this condition. Therefore, standard errors of our estimates are robust in regard to autocorrelation and heteroscedasticity and we can draw valid inferences from the results. We also run a regression of equation (1) for a limited data sample (similarly to Andersen et al. 2007 and Fatum et al. 2012) - only with observations 10 minutes before the announcement and 90 minutes after the announcements in order to check for possible longer term variance patterns which could influence the results. However, we are generally not able to find different results.

\section{Empirical data and analysis}

We use a combination of CROBEX data from the Zagreb Stock Exchange (ZSE) and public announcements. CROBEX is the official ZSE index including between 15 and 25 major stocks trading on more than $80 \%$ of the trading days. A single traded stock is weighed at maximum $10 \%$. The ZSE started publishing the CROBEX index on September 1, 1997 with base value set on 1000 points. The composition of CROBEX is changed and adjusted semi-annually to best represent the movement of the capital market. At present, CROBEX represents a weighted average market price of 16 Croatian stocks with the highest rank which are listed in the regulated market and traded more than $80 \%$ of available trading days in the previous six-month period. The key element is the number of stocks that can be freely traded on the market (free float stocks). This excludes issuer's own (treasury) 
stocks and those owned and controlled by $5 \%$ or more of the total outstanding in the respective issue. Securities in custody accounts are always included in free float.

Data used in this study cover the period from 9:30, $5^{\text {th }}$ of September 2017 to 16:00, $19^{\text {th }}$ of March 2018. Main source of both data types, i.e. logarithmic five-minute rates of return and macroeconomic announcements is the Bloomberg database. We analysed stock market sessions from 9:30 to 16:00. Total number of five-minute rates of return is equal to 52126 observations. During the data preparation phase, we applied an approach similar to the one found in Andersen et al. (2007) i.e. in our database, we included only the days on which there was at least one transaction every 30 minutes. Observations not fulfilling this criterion were removed from the database (the total of 10 days, usually holidays: the total of 1924 observations). The decision to choose five-minute intervals is also based on previous studies (Andersen et al. 2007, Andersen et al. 2003). Because many macroeconomic announcements were released during the same day and within the same hour, we excluded such recurring data from the database. From the total of 84 macroeconomic announcements released during the analysed period, 25 are not recurring, nonoverlapping (i.e. one release at given time). In table 1, we summarize the number of each macroeconomic release (event) that we use as dummy in equation (1). Table 3 in Appendix contains original data from the Bloomberg database.

Table 1: Macroeconomic announcements characteristics

\begin{tabular}{|l|c|}
\hline \multicolumn{1}{|c|}{ Announcement } & Number of events \\
\hline Current Account Balance & 2 \\
\hline GDP YoY & 2 \\
\hline Industrial Output YoY & 1 \\
\hline Money Supply M1 Level & 6 \\
\hline Real Wages YoY & 2 \\
\hline Retail Trade Real YoY & 3 \\
\hline Trade Balance & 3 \\
\hline Unemployment Rate & 6 \\
\hline
\end{tabular}

Source: author's, year of calculation - 2019, based on Bloomberg database.

An important feature of intraday financial data is the specific U-shaped variance distribution throughout the market session. Higher variance is recognized to exist at the beginning and the end of a day, due to higher intensity of trades related to these periods. Similar shape can be observed in the case of the CROBEX index (figure 1). Such variance clustering is responsible for heteroscedasticity in processes described in equation (1) and this is the reason for which we use heteroscedasticity and serialcorrelation robust (HAC) standard errors. 
Figure 1: Average five-minute standard d eviation for the analyzed period.

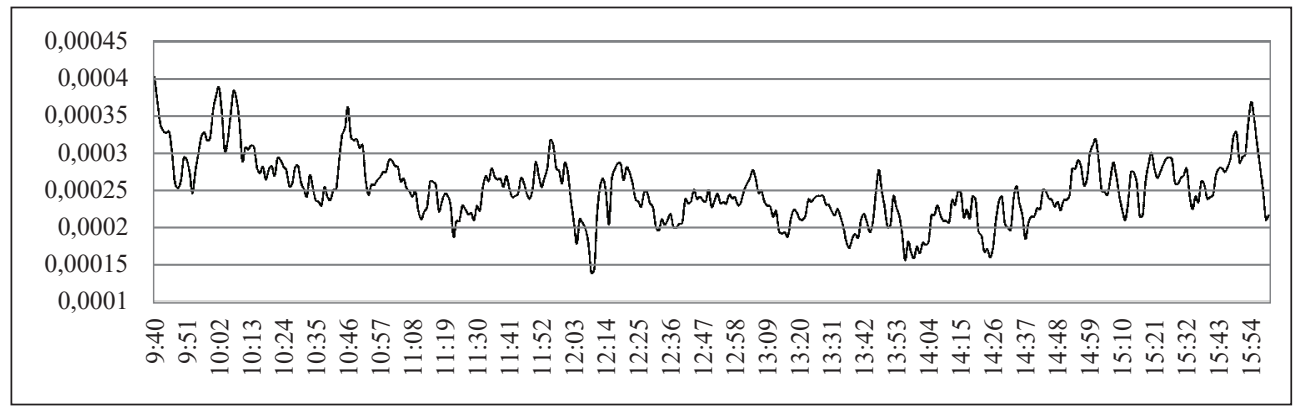

Source: author's, year of calculation - 2019, based on CROBEX data.

In order to recognize which of the macroeconomic announcements impact the CROBEX index the most, we analyse the significance of coefficients estimates $\beta_{j, k}$ from equation (1). Unfortunately, as we do not possess all the information of expected values for these variables, we do not focus on the signs or values of these estimates. We use this approach to dismiss any biasness which could potentially be induced by lack of information. Financial theory suggests that only unexpected changes in macroeconomic environment should be reflected in assets prices, but as we cannot ascertain such unexpected deviations (we do not have market expectations data), we concentrate only on selecting the variables that measurably influenced the market. We do expect information on cost factors to be statistically significant as it is important for profit calculation. Revenue growth information is largely contained in GDP growth: the other statistically significant variable. As for other variables, we could not test for enterprise specific information, as during the observed period there weren't any. Our main results are presented in Table 2. We do not present estimates related to $\beta_{m}$ for purpose of brevity.

Table 2: Equation (1) estimation results

\begin{tabular}{|l|r|c|c|}
\hline \multicolumn{1}{|c|}{ Variable } & Coefficient & t-Statistic & Prob. \\
\hline CURR_ACC(2) & $-0,000013$ & $-0,05$ & 0,96 \\
\hline CURR_ACC(1) & 0,000054 & 0,21 & 0,83 \\
\hline CURR_ACC & $-0,000142$ & $-0,56$ & 0,58 \\
\hline CURR_ACC(-1) & 0,000037 & 0,15 & 0,88 \\
\hline CURR_ACC(-2) & $-0,000013$ & $-0,05$ & 0,96 \\
\hline GDP(2) & 0,000020 & 0,08 & 0,94 \\
\hline GDP(1) & 0,000057 & 0,22 & 0,82 \\
\hline GDP & 0,000034 & 0,13 & 0,90 \\
\hline GDP(-1) & $-0,000662^{* * *}$ & $-2,60$ & 0,01 \\
\hline GDP(-2) & $-0,000127$ & $-0,50$ & 0,62 \\
\hline IND_PROD(2) & $-0,001907^{* * *}$ & $-5,30$ & 0,00 \\
\hline
\end{tabular}


Tomasz Schabek, Bojana Olgić Draženović, Davor Mance • Reaction of Zagreb Stock...

\begin{tabular}{|l|r|r|c|}
\hline \multicolumn{1}{|c|}{ Variable } & Coefficient & t-Statistic & Prob. \\
\hline IND_PROD(1) & $-0,000233$ & $-0,65$ & 0,52 \\
\hline IND_PROD & $-0,000466$ & $-1,29$ & 0,20 \\
\hline IND_PROD(-1) & $-0,000051$ & $-0,14$ & 0,89 \\
\hline IND_PROD(-2) & $-0,000225$ & $-0,62$ & 0,53 \\
\hline M1(2) & $-0,000015$ & $-0,10$ & 0,92 \\
\hline M1(1) & 0,000003 & 0,02 & 0,98 \\
\hline M1 & $-0,000137$ & $-0,93$ & 0,35 \\
\hline M1(-1) & $0,000275^{*}$ & 1,87 & 0,06 \\
\hline M1(-2) & 0,000225 & 1,53 & 0,13 \\
\hline REAL_WAGE(2) & 0,000064 & 0,25 & 0,80 \\
\hline REAL_WAGE(1) & 0,000186 & 0,73 & 0,46 \\
\hline REAL_WAGE & $-0,000087$ & $-0,34$ & 0,73 \\
\hline REAL_WAGE(-1) & $-0,001026 * * *$ & $-4,03$ & 0,00 \\
\hline REAL_WAGE(-2) & $-0,000325$ & $-1,27$ & 0,20 \\
\hline RET_TRADE(2) & $-0,000003$ & $-0,01$ & 0,99 \\
\hline RET_TRADE(1) & 0,000003 & 0,01 & 0,99 \\
\hline RET_TRADE & 0,000032 & 0,15 & 0,88 \\
\hline RET_TRADE(-1) & 0,000005 & 0,03 & 0,98 \\
\hline RET_TRADE(-2) & 0,000028 & 0,13 & 0,90 \\
\hline TRADE_BALAN(2) & 0,000029 & 0,14 & 0,89 \\
\hline TRADE_BALAN(1) & 0,000005 & 0,02 & 0,98 \\
\hline TRADE_BALAN & $-0,000050$ & $-0,24$ & 0,81 \\
\hline TRADE_BALAN(-1) & $-0,000005$ & $-0,03$ & 0,98 \\
\hline TRADE_BALAN(-2) & 0,000032 & 0,15 & 0,88 \\
\hline UNEMPL(2) & 0,000070 & 0,47 & 0,64 \\
\hline UNEMPL(1) & $-0,000015$ & $-0,10$ & 0,92 \\
\hline UNEMPL & 0,000117 & 0,79 & 0,43 \\
\hline UNEMPL(-1) & $-0,000008$ & $-0,05$ & 0,96 \\
\hline UNEMPL(-2) & 0,000055 & 0,37 & 0,71 \\
\hline C & $0,000031 * * *$ & 3,61 & 0,00 \\
\hline & & & \\
\hline & & & \\
\hline & & & \\
\hline & & & \\
\hline
\end{tabular}

Notes: The first column enumerates the macroeconomic variables with period leads one and two being marked (1) and (2) next to the name of variable. The period lags one and two, are marked as $(-1)$ and (-2). Five-minute rates of return was calculated as: $\ln \left(\frac{P_{t}}{P_{t-5}}\right)$, where $\mathrm{P}_{\mathrm{t}}$ is the index value in moment $t$, and $\mathrm{P}_{\mathrm{t}-5}$ is the index value 5 minutes earlier. The second column contains estimates of $\beta_{j, k}$ from equation (1). The third column represents HAC standard errors and the last two columns contain t-statistics and p-values. CURR_ACC stands for current account balance, IND_PROD (YoY) - industrial output (YoY), GDP - gross domestic product (YoY), M1 - monetary aggregate M1 level, REAL_WAGE - real wages (YoY), TRADE_BALAN - trade balance, UNEMPL - unemployment rate. Control variables: dummy variables and leads/lags of five-minute rate of return of EUR50 Index, not presented - for brevity sake.

Source: author's calculations, year of calculation - 2019 
As visible in table 2, only four macroeconomic variables: GDP, industrial production, $\mathrm{M} 1$ and real wages are significant. The rest of the variables are insignificant.

\section{Results and discussion}

Most of the variables are insignificant and this means the market does not react to macroeconomic releases regarding these variables. Four macroeconomic variables that were found to be significant mainly describe the real sphere of the Croatian economy (industrial production and real wages), but also the monetary sphere of the economy (M1). This may indicate that the Croatian stock market is particularly sensitive to variables describing the real sphere of the Croatian economy like industrial production, but also the monetary sphere of the economy. One of the reasons for the sensitivity regarding the real sphere is that Croatian economic growth is primarily based on the growth of personal consumption component of the domestic demand, as well as the rise of salaries and employment (EC, 2018). Any news correcting expectations regarding these factors would have an impact on the CROBEX. The reason for the sensitivity regarding the monetary sphere is the Croatian past abuse of the monetary system for macroeconomic purposes, and the inherent fear of inflation. Croatia benefits from a currency board as M1 money supply is the primary Granger cause of inflation in Croatia (Mance et al, 2015). Also, Croatia needs the adherence to the euro, as Kuna still does not have a fully accepted money status and needs monetary stability for EMU integration (Mance et al. 2019). Monetary stability is an important segment of the overall macroeconomic stability as well as a proof of commitment to full EU market integration. Integrated markets trade more, and more trade results in higher stock market values. Because of data unavailability we could not acquire data which would describe our announcements more precisely, i.e. divide them into groups of expected and unexpected ("surprise") announcements. Therefore, we can't be sure if our significant variables indicate market inefficiency or they indicate just surprises in these announcements. But the majority of coefficients are statistically insignificant. Thus, our results, in general, support the semi-strong form of the efficient-market hypothesis. It seems, that in the case of a relatively small Croatian market, the stock exchange is concentrated on few but important macroeconomic data. Information is by definition newly acquired knowledge, and markets do economise with knowledge: information already gained or contained in other sources is of no additional market value, and thus is expected to be of no statistical significance. For example, current account information is expected, economic theory commensurate and already contained in previously announced information about government deficit and foreign investment. If large deficits of government budgets do not exist, current account deficits are consequences of foreign investment. Information on foreign investment as well as information on government finances is publicly disclosed before the current account information. 
Information regarding real wages is important for future investment in both tradeable as well as non tradeable sectors as unit labour costs are an important cost factor, and due to Baumol-Bowen effects, spill overs from the former will inevitably occur into the latter sector. Information on unemployment is not that important as it is not a direct cost factor as for example unit labour costs or information on labour utilisation. Due to emigration, the unemployment in Croatia has been falling, but labour utilisation remained low (EC, 2018). Costfactor wise no new direct information relevant to CROBEX is contained in the data on unemployment.

As noted previously, the CROBEX stock index includes the most traded and liquid stock companies listed on the ZSE. It is measured continuously using free float market capitalization, using the latest stock prices, where the weight of each individual stock is limited to a maximum of 10 percent. Thus, the results of this study also reflect the overall composition of the underlying index: the most of the listed companies being enterprises producing and exporting industrial products. The results display the reaction of CROBEX to be somewhat lagged in time, dependent on the nature of the information showing that the market reacts cautiously to information regarding industrial production and trade balance. Other information does not seem to be significant at $\mathrm{p}<0.01$ level. Influence of industrial production on financial market volatility is confirmed also by other researchers like BędowskaSójka (2013) for French and German markets, Fatum et al. (2012) for Japanese market, Gurgul et al. (2016) for Polish market.

Our results contribute to the literature in several ways. Firstly, we provide an analysis of intraday data related to Croatian stock market - the topic that was not investigated in up-to-date literature. Secondly, our results confirm semi-strong form of the efficient-market hypothesis in context of impact of macroeconomic data on rates of returns from CROBEX index. Thirdly, we identified some potential macroeconomic variables which could be closely observed by investors and employed in investing strategies. Finally, the results show which of the analysed announcements could potentially be of higher importance to policy makers in case they would like to carry out policies influencing the Croatian capital market. The findings represent an important contribution to the existing literature about the efficiency of the Croatian stock market as they clearly indicate that market returns react to macroeconomic information regarding monetary economics and the real economic sector.

Our research could be extended over a longer period of time and could include other relevant financial or fiscal indicators. Even without this, our results are useful to researchers, investors and other capital market participants, as well as to policy makers as they provide a theoretical framework within which one can ground its policies to achieve an even more efficient and liquid capital market in Croatia. 


\section{Conclusions}

We performed the effect study of macroeconomic information on the most important stock price index on the Croatian capital market: the CROBEX. We tested the semi-strong form of the efficient-market hypothesis implying that the index already integrated the most relevant technical and fundamental information regarding individual enterprises contained in the index. Thus, we tested for the integration of remaining relevant macroeconomic information. We used heteroscedasticity and autocorrelation consistent (HAC) estimations in order to account for specific characteristics of intraday data and retain the robustness of results. Some results for short intraday periods are statistically significant, but most of the coefficients stay insignificant, indicating that CROBEX well reflects market expectations. The results favour the non-rejection of the semi-strong form of the efficient-market hypothesis. As most of the listed enterprises are from the industrial sector, it is expected that their prices respond to aggregate information on industrial production. Croatia is an economy with a significant share of services and industry in the GDP. For these reasons, the results regarding industrial production and real wages are in line with the economic intuition and reasoning. Finally, we may conclude, that our results, in general, support the semi-strong form of the efficient-market hypothesis due to the behaviour of the most liquid component of the Croatian capital market: the CROBEX index of the Zagreb Stock Exchange. Our research has some limitations as well. We could neither test for the reactions on deviations from market expectation (surprises) as we were not able to acquire expected macroeconomic data, nor test for trading strategies exploiting the fact of significant reactions to macroeconomic data, which could shed more light on semi-strong efficiency. However, these improvements and ideas pose interesting questions and present the possibility for future research of Croatian stock market efficiency.

\section{References}

Andersen, T. G., Bollerslev, T., Diebold, F. X., Vega, C. (2003) "Micro Effects of Macro Announcements: Real-Time Price Discovery in Foreign Exchange", American Economic Review, Vol. 93, No. 1, pp. 38-62, http://doi.org/10.1257/ 000282803321455151.

Andersen, T. G., Bollerslev, T., Diebold, F. X., Vega, C. (2007) "Real-time price discovery in global stock, bond and foreign exchange markets", Journal of International Economics, Vol. 73, No. 2, pp. 251-277, http://doi.org/10.1016/j. jinteco.2007.02.004.

Andritzky, J. R., Bannister, G. J., Tamirisa, N. T. (2007) "The impact of macroeconomic announcements on emerging market bonds", Emerging Markets Review, Vol. 8, No. 1, pp. 20-37, http://doi.org/10.1016/j.ememar.2006.05.001. 
Baranowski, P., Gajewski, P. (2016) "Credible enough? Forward guidance and perceived National Bank of Poland's policy rule", Applied Economics Letters, Vol. 23, No. 2, pp. 89-92, http://doi.org/10.1080/13504851.2015.1051651.

Baillie, R. T., Bollerslev, T. (1991) "Intra-Day and Inter-Market Volatility in Foreign Exchange Rates", The Review of Economic Studies, 58(3), pp. 565585, http://doi.org/10.2307/2298012.

Barbić, T., Čondić-Jurkić, I. (2017) "Do fiscal Variables Affect Stock Market Returns in EU? Panel Data Analysis", Ekonomski pregled, Vol. 68, No. 3, pp. 253-266.

Barbić, T., Čondić-Jurkić, I. (2011) "Relationship between macroeconomic fundamentals and stock market indices in selected CEE countries", Ekonomski pregled, Vol. 62, No. 3-4, pp. 113-133.

Będowska-Sójka B. (2013) "Macroeconomic news effects on the stock markets in intraday data, Central", European Journal of Economic Modelling and Econometrics, Vol. 5, pp. 249-269.

Będowska-Sójka, B. (2016) "Liquidity Dynamics Around Jumps: The Evidence from the Warsaw Stock Exchange", Emerging Markets Finance and Trade, Vol. 52, No. 12, pp. 2740-2755, http://doi.org/10.1080/1540496X.2016.1216937.

Benaković, D., Posedel, P. (2010) "Do macroeconomic factors matter for stock returns? Evidence from estimating a multifactor model on the Croatian market", Business Systems Research, 1 (1-2), pp. 39-46, http://doi.org/10.2478/v10305012-0023-z.

Benić, V., Franić, I. (2008) "Stock Market Liquidity: Comparative Analysis of Croatian and Regional Markets", Financial Theory and Practice, Vol. 32, No. 4, pp. 477-498.

Bień-Barkowska, K. (2014) "Capturing Order Book Dynamics in the Interbank EUR/PLN Spot Market”, Emerging Markets Finance and Trade, Vol. 50, No. 1, pp. 93-117, http://doi.org/10.2753/REE1540-496X500105.

Brzeszczyński, J., Gajdka, J., Kutan, A. M. (2017) "Central Bank Communication and the Impact of Public Announcements of New Monetary Policy Data on the Reaction of Foreign Exchange and Stock Markets: Evidence from Poland", Argumenta Oeconomica, Vol. 2, No. 39, pp. 21-60, http://doi.org/10.15611/aoe.2017.2.02.

Buljat, M., Ivanović, Z., Bareša, S. (2015) "Analysis of the Capital Market in Croatia”, UTMS Journal of Economics, Vol. 6, No. 2, pp. 223-232.

Cai, F., Joo, H., Zhang, Z. (2009) "The impact of macroeconomic announcements on real time foreign exchange rates in emerging markets", International Finance Discussion Papers 973, Board of Governors of the Federal Reserve System (U.S.). Available at $<$ https://ideas.repec.org/p/fip/fedgif/973.html $>$.

DeGennaro, R. P., Shrieves, R. E. (1997) "Public information releases, private information arrival and volatility in the foreign exchange market" Journal of Empirical Finance, 4(4), 295-315, http://doi.org/10.1016/S0927-5398(97)00012-1. 
Égert B., Kocenda E. (2007) “Interdependence between Eastern and Western European stock markets: Evidence from intraday data", Economic Systems Volume, Vol. 31, No. 2, pp. 184-203, dhttp://doi.org/10.1016/j.ecosys.2006.12.004.

European Commission (2018) Country Report Croatia 2018 Including an In-Depth Review on the prevention and correction of macroeconomic imbalances No 209 European Union, Brussels. Available at $<$ https:/ec.europa.eu/info/sites/info/ files/2018-european-semester-country-report-croatia-en.pdf $>$.

Fama, E.F., (1970) "Efficient Capital Markets: A Review of Theory and Empirical Work" Journal of Finance, vol. 25, No. 2, pp. 383-417.

Fama, E.F., French, K.R. (1992) "The Cross-Section of Expected Stock Returns" The Journal of Finance, Vol. 47, No. 2, pp. 427-465.

Fatum, R., Hutchison M., Wu, T. (2012) "Asymmetries and State Dependence: The Impact of Macro Surprises on Intraday Exchange Rates" Journal of the Japanese and International Economies 26 (4): 542-60, http://doi.org/10.1016/j. jjie.2012.08.004.

Frömmel, M., Han, X., Van Gysegem, F. (2015) "Further Evidence on Foreign Exchange Jumps and News Announcements", Emerging Markets Finance \& Trade, Vol. 51, No. 4, pp. 774-787, http://doi.org/10.1080/1540496X.2015.1046348.

Grubišić Šeba, M. (2017) "20 Years of the Croatian Capital Market", Zagreb International Review of Economics and Business, Vol. 20, No. 1, pp. 41-58, http://doi.org/10.1515/zireb-2017-0004.

Gurgul, H., Lach, L., Wojtowicz, T. (2016) "Impact of US Macroeconomic News Announcements on Intraday Causalities on Selected European Stock Markets", Czech Journal of Economics and Finance (Finance a Uver), Vol. 66, No. 5, pp. 405-425.

Hanousek, J., Kočenda, E., Kutan, A. M. (2009) "The reaction of asset prices to macroeconomic announcements in new EU markets: Evidence from intraday data", Journal of Financial Stability, Vol 5, No. 2, pp. 199-219, http://doi. org/10.1016/j.jfs.2008.01.003.

Hanousek, J, Novotný J (2012) „Price jumps in Visegrad-country stock markets: An empirical analysis“. Emerging Markets Review, Vol. 13, No. 2, pp. 184-201, http://doi.org/10.1016/j.ememar.2012.01.005.

Hsing, Y. (2011) „Macroeconomic variables and the stock market: the case of Croatia", Ekonomska istraživanja, Vol. 24, No. 4, pp. 41-50.

Huang, X. (2018) "Macroeconomic news announcements, systemic risk, financial market volatility, and jumps", Journal of Futures Markets, Vol. 38, No. 5, pp. 513-534, http://doi.org/10.1002/fut.21898.

Jakšić, S. (2008) "Utjecaj monetarnog agregata M4 i kamatnih stopa na CROBEX”, Zbornik Ekonomskog fakulteta u Zagrebu, Vol. 6, No. 1, pp. 131-139.

Lahaye, J., Laurent, S., Neely, C. J. (2011) "Jumps, cojumps and macro announcements". Journal of Applied Econometrics, 26(6), 893-921, http://doi.org/10.1002/jae.1149. 
Li, W., Wong, M. C. S., Cenev, J. (2015) "High Frequency Analysis of Macro News Releases on the Foreign Exchange Market: A Survey of Literature" Big Data Research, Vol. 2, No. 1, pp. 33-48, http://doi.org/10.1016/j.bdr.2015.02.003.

Logožar, T., Arnerić, J. (2017). "Neparametarski procjenitelji volatilnosti", Oeconomicus, Vol. 1, No. 3, pp. 8-19.

Mance, D., Žiković, S., Mance, D. (2015) "Econometric Analysis of Croatia's Proclaimed Foreign Exchange Rate",The South East European Journal of Economics and Business, Vol. 10, No. 1, http://doi.org/10.1515/jeb-2015-0001.

Mance, D. Drazenovic B. O.; Nikolaj S. S. (2019) "Croatian Kuna: Money, or Just a Currency? Evidence from the Interbank Market", UTMS Journal of Economics, Vol. 10, No. 2, pp. 149-161.

Maserumule, T., Alagidede, P. (2017) "Impact of Macroeconomic Announcements on Foreign Exchange Volatility: Evidence from South Africa", South African Journal of Economics, Vol. 85, No. 3, pp. 405-429, http://doi.org/10.1111 saje.12160.

Nadler, D., Schmidt, A. B. (2016) "Impact of Macroeconomic Announcements on US Equity Prices: 2009-2013”, Journal of Forecasting, Vol. 35, No. 1, pp. 34 42, http://doi.org/10.1002/for.2359.

Newey, W. K., West, K. D. (1987) "A Simple, Positive Semi-Definite, Heteroskedasticity and Autocorrelation Consistent Covariance Matrix", Econometrica, Vol. 55, No. 3, pp. 703-708, http://doi.org/10.2307/1913610.

Nikkinen, J., Omran, M., Sahlström, P., Äijö, J. (2006) “Global stock market reactions to scheduled U.S. macroeconomic news announcements", Global Finance Journal, Vol. 17, No. 1, pp. 92-104, http://doi.org/10.1016/j.gfj.2006.06.003.

Peša, A. R., Festić, M. (2012) „Testing the "EU announcement effect” on stock market indices and macroeconomic variables in Croatia between 2000 and 2010“, Prague Economic Papers, Vol. 4, pp. 450-469.

Rozkrut, M., Rybiński, K., Sztaba, L., \& Szwaja, R. (2007) "Quest for central bank communication: Does it pay to be 'talkative'?", European Journal of Political Economy, Vol. 23, No. 1, pp. 176-206, http://doi.org/10.1016/j.ejpoleco.2006. 09.011 .

Sajter, D., Čorić, T. (2009) "(I).rationality of Investors on Croatian Stock Market Explaining the Impact of American Indices on Croatian Stock Market", Zagreb International Review of Economics and Business, Vol.12, No. 2, pp. 57-72.

Schabek. T, Maknickienė N, (2018) "Influence of macroeconomic factors on stock prices in Poland - cross section and time series analysis". In Conference Proceedings 10th International Scientific Conference „Business and Management 2018“, 3-4 May, Vilnius, Lithuania, pp. 491-487, http://doi. org/10.3846/bm.2018.54.

Shim, H., Kim, M. H., Ryu D. (2017) "Effects of intraday weather changes on asset prices", Zbornik radova Ekonomskog fakulteta Rijeka, Vol. 35, no. 2, pp. 301330, http://doi.org/10.18045/zbefri.2017.2.301. 
Škrinjarić, T., Besek, B. (2014) "Pre and Post Crisis Performance Measurement of Croatian Stock Market", Zagreb International Review of Economics \& Business, Vol. 17, No. 2, pp. 97-116.

Vidović, J. (2013) "Investigation of stock illiquidity on Central and South East European markets in naive portfolio framework", Ekonomska misao i praksa, No.2, pp. 537-550.

ZSE (2019) CROBEX revisions. Available at: <http://www.zse.hr/default. aspx? $\mathrm{id}=44102 \&$ inde $\mathrm{x}=\mathrm{CROBEX}>$.

ZSE (2017) Resolution on the CROBEX® index. Available at: <http://zse.hr/ UserDocsImages/dokumenti_indeksi/CROBEX_20170209142405-2017CROBEX-Resolution\%20ENG.pdf>. 


\title{
Reakcije CROBEX indeksa Zagrebačke burze na makroekonomske najave $\mathrm{u}$ visoko frekventnim intervalima ${ }^{1}$
}

\author{
Tomasz Schabek ${ }^{2}$, Bojana Olgić Draženović ${ }^{3}$, Davor Mance ${ }^{4}$
}

\begin{abstract}
Sažetak
Svrha ovog rada je analizirati reakcije CROBEX indeksa Zagrebačke burze na odabrane makroekonomske najave u vrlo kratkim vremenskim intervalima. U radu se koriste varijable stopa prinosa od 5 minuta od rujna 2017. do ožujka 2018. kao i 25 makroekonomskih najava. Nakon pažljive provedbe faze pripreme podataka, utvrđena je regresija za koju se koriste dummy varijable koje predstavljaju točno vrijeme objavljivanja. U obzir je uzeta heteroskedastičnost $i$ autokorelacijske konzistentne (HAC) procjene zbog specifičnosti unutardnevnih podataka $i$ robusnosti rezultata. Naši rezultati upućuju na to da su za unutardnevna kratka razdoblja reakcije tržišta statistički značajne. Stoga se zaključuje da se makroekonomska politika (monetarna ili fiskalna) odražava na stope prinosa hrvatskih dioničkih indeksa. Navedeno potvrđuje hipotezu učinkovitog tržišta i u skladu su sa zaključcima sličnih studija razvijenih gospodarstava.
\end{abstract}

Ključne riječi: tržišta u nastajanju, hrvatsko financijsko tržište, makroekonomske najave, unutardnevni prinosi, CROBEX

JEL klasifikacija: G1, F3, E5, O2, P3

${ }^{1}$ Ovaj znanstveni članak je primio potporu Sveučilišta u Rijeci, projekt broj: uniri-drustv-18-61. Ovaj znanstveni članak je primio potporu Sveučilišta u Rijeci, projekt broj: uniri-drustv18-284-1456.

2 Docent, Sveučilište Lodz, Fakultet ekonomije i sociologije, POW 3/5, 90-255 Lodz, Poljska. Znanstveni interes: financijska ekonometrija, financije, bihevioralne financije, tržišta kapitala. Tel.: +48889162263.E-mail: tomasz.schabek@uni.lodz.pl.

${ }^{3}$ Docent, Sveučilište u Rijeci, Ekonomski fakultet, I. Filipovića 4, 51000 Rijeka, Hrvatska. Znanstveni interes: tržište kapitala, institucionalni investitori, mirovinski sustavi. Tel.: +38551 355128.E-mail: bojana.olgic.drazenovic@efri.hr.

${ }^{4}$ Docent, Sveučilište u Rijeci, Ekonomski fakultet, I. Filipovića 4, 51000 Rijeka, Hrvatska. Znanstveni interes: institucionalna i bihevioralna ekonomija. Tel.: +385 51 355144. E-mail: davor.mance@efri.hr. 


\section{Appendix}

Table 3. Original macroeconomic announcements from the Bloomberg database

\begin{tabular}{|c|c|c|c|c|}
\hline Date Time & Event & Period & Actual & Prior \\
\hline 09/08/17 05:00 & Retail Trade Real YoY & Jul & $5.9 \%$ & $6.0 \%$ \\
\hline 09/22/17 05:00 & Unemployment Rate & Aug & $10.9 \%$ & $10.8 \%$ \\
\hline 09/29/17 08:11 & Current Account Balance & $2 \mathrm{Q}$ & $143.8 \mathrm{~m}$ & $-1527.6 \mathrm{~m}$ \\
\hline 09/29/17 08:20 & Money Supply M1 Level & Aug & $96411.9 \mathrm{~m}$ & $93494.8 \mathrm{~m}$ \\
\hline 10/09/17 05:22 & Trade Balance & Jul & -5419 & -5056 \\
\hline 10/20/17 05:00 & Unemployment Rate & Sep & $10.8 \%$ & $10.9 \%$ \\
\hline 10/31/17 06:00 & Real Wages YoY & Aug & $3.6 \%$ & $3.3 \%$ \\
\hline $10 / 31 / 1707: 25$ & Money Supply M1 Level & Sep & $95956.6 \mathrm{~m}$ & $96411.9 \mathrm{~m}$ \\
\hline 11/22/17 05:00 & Unemployment Rate & Oct & $11.6 \%$ & $10.8 \%$ \\
\hline 11/30/17 09:35 & Money Supply M1 Level & Oct & $94938.9 \mathrm{~m}$ & $95956.6 \mathrm{~m}$ \\
\hline 12/01/17 05:00 & GDP YoY & $3 Q$ & $3.3 \%$ & $3.3 \%$ \\
\hline 12/07/17 05:00 & Trade Balance & Sep & -5370 & -4501 \\
\hline 12/22/17 05:00 & Unemployment Rate & Nov & $12.1 \%$ & $11.6 \%$ \\
\hline 12/29/17 07:05 & Current Account Balance & $3 Q$ & $3868.2 \mathrm{~m}$ & $143.8 \mathrm{~m}$ \\
\hline 12/29/17 07:18 & Money Supply M1 Level & Nov & $94832.6 \mathrm{~m}$ & $94938.9 \mathrm{~m}$ \\
\hline 01/10/18 05:00 & Retail Trade Real YoY & Nov & $5.7 \%$ & $5.7 \%$ \\
\hline 01/23/18 05:00 & Unemployment Rate & Dec & $12.2 \%$ & $12.1 \%$ \\
\hline 01/29/18 05:00 & Industrial Output YoY & Dec & $-2.5 \%$ & $-1.7 \%$ \\
\hline 01/30/18 05:00 & Retail Trade Real YoY & Dec & $1.4 \%$ & $5.7 \%$ \\
\hline 01/31/18 05:00 & Real Wages YoY & Nov & $3.8 \%$ & $3.7 \%$ \\
\hline 01/31/18 09:35 & Money Supply M1 Level & Dec & $99436.3 \mathrm{~m}$ & $94832.6 \mathrm{~m}$ \\
\hline 02/22/18 06:29 & Unemployment Rate & Jan & $12.7 \%$ & $12.2 \%$ \\
\hline 02/28/18 09:37 & Money Supply M1 Level & Jan & $97132.0 \mathrm{~m}$ & $99436.3 \mathrm{~m}$ \\
\hline 03/02/18 05:00 & GDP YoY & $4 Q$ & $2.0 \%$ & $2.0 \%$ \\
\hline 03/08/18 05:00 & Trade Balance & Dec & -3591 & -3439 \\
\hline
\end{tabular}

Source: the Bloomberg database, 2019. Note: EDT time zone (in our analysis we convert it to Croatian time) 